\title{
Effect of dietary crude protein degradability and corn processing on lactation performance and milk protein composition and stability
}

\author{
C. M. M. R. Martins, ${ }^{1}$ D. C. M. Fonseca, ${ }^{1}$ B. G. Alves, ${ }^{1}$ M. A. Arcari, ${ }^{1}$ G. C. Ferreira, ${ }^{1}$ K. C. Welter, ${ }^{2}$ \\ C. A. F. Oliveira, ${ }^{3}$ F. P. Rennó, ${ }^{1}$ and M. V. Santos ${ }^{1 *}$ \\ ${ }^{1}$ Department of Animal Nutrition and Production, School of Veterinary Medicine and Animal Science, University of São Paulo, \\ Pirassununga 13635-900, São Paulo, Brazil \\ ${ }^{2}$ Department of Animal Science, School of Food Engineering and Animal Science, University of São Paulo, Pirassununga 13635-900, São Paulo, \\ Brazil \\ ${ }^{3}$ Department of Food Engineering, School of Food Engineering and Animal Science, University of São Paulo, Pirassununga 13635-900, \\ São Paulo, Brazil
}

\section{ABSTRACT}

The present study aimed to evaluate the effect of crude protein degradability and corn processing on lactation performance, milk protein composition, milk ethanol stability (MES), heat coagulation time (HCT) at $140^{\circ} \mathrm{C}$, and the efficiency of $\mathrm{N}$ utilization for dairy cows. Twenty Holstein cows with an average of 162 $\pm 70 \mathrm{~d}$ in milk, $666 \pm 7 \mathrm{~kg}$ of body weight, and 36 $\pm 7.8 \mathrm{~kg} / \mathrm{d}$ of milk yield (MY) were distributed in a Latin square design with 5 contemporaneous balanced squares, 4 periods of $21 \mathrm{~d}$, and 4 treatments (factorial arrangement $2 \times 2$ ). Treatment factor 1 was corn processing [ground (GC) or steam-flaked corn (SFC)] and factor 2 was crude protein $(\mathrm{CP})$ degradability (high $=10.7 \%$ rumen-degradable protein and $5.1 \%$ rumenundegradable protein; low $=9.5 \%$ rumen-degradable protein and $6.3 \%$ rumen-undegradable protein; dry matter basis). A significant interaction was observed between CP degradability and corn processing on dry matter intake (DMI). When cows were fed GC with low CP degradability, DMI increased by $1.24 \mathrm{~kg} / \mathrm{d}$ compared with cows fed GC with high CP degradability; however, CP degradability did not change DMI when cows were fed SFC. Similar interactions were observed for MY, HCT, and lactose content. When cows were fed GC diets, high CP degradability reduced MY by $2.3 \mathrm{~kg} / \mathrm{d}$, as well as HCT and lactose content, compared with low CP degradability. However, no effect of CP degradability was observed on those variables when cows were fed SFC diets. The SFC diets increased dry matter and starch total-tract digestibility and reduced $\beta$-casein $(\mathrm{CN})$ content (\% total milk protein) compared with GC diets. Cows fed low-CP degradability diets

Received August 14, 2018.

Accepted January 22, 2019.

*Corresponding author: mveiga@usp.br had higher glycosylated $\kappa-\mathrm{CN}$ content $(\%$ total $\kappa-\mathrm{CN})$ and MES, as well as milk protein content, $3.5 \%$ fatcorrected milk, and efficiency of $\mathrm{N}$ for milk production, than cows fed high-CP degradability diets. Therefore, GC and high-CP degradability diets reduced milk production and protein stability. Overall, low CP degradability increased the efficiency of dietary $\mathrm{N}$ utilization and MES, probably due to changes in casein micelle composition, as CP degradability or corn processing did not change the milk concentration of ionic calcium. The GC diets increased $\beta$-CN content, which could contribute to reducing HTC when cows were fed GC and high-CP degradability diets.

Key words: casein, glycosylation, heat stability, ethanol test

\section{INTRODUCTION}

Milk ethanol stability (MES) testing has been used for several decades in the dairy industries of some countries to estimate milk heat stability problems because of acidic milk due to microbial spoilage. In these countries, the MES test is used as the primary method of on-farm milk quality evaluation. However, MES is affected by factors other than milk acidification, because milk samples with normal acidity and low bacterial counts may also have ethanol instability (Fischer et al., 2012). Previous studies have described that other factors, such as nutrition (Barbosa et al., 2012; Stumpf et al., 2013), metabolic disorders (Fagnani et al., 2014; Martins et al., 2015), and genetics of cows, can reduce milk stability (Fischer et al., 2012). Moreover, MES can also be an issue for alcoholic dairy beverage production, due to the possible presence of protein clots in the product (Fagnani et al., 2016).

Among nutritional factors, it was reported that nutrient deficiency can reduce MES (Barbosa et al., 2012; Stumpf et al., 2013). Feed restriction increases 
permeability of the mammary gland cell tight junctions, facilitating ion passage, such as ionic calcium (iCa), from blood to milk (Stumpf et al., 2013). The increase of $\mathrm{iCa}$ in milk reduces the negative charge of casein micelles and the strength of electrostatic repulsion between them, which facilitates milk coagulation as determined by an ethanol test (Barros et al., 1999). Moreover, Barbosa et al. (2012) reported that ethanolunstable milk had lower concentration of $\kappa-\mathrm{CN}$ than milk ethanol-stable samples. $\kappa$-Casein is the hydrophilic and Ca-stable casein subunit, playing an essential role in the protection of the hydrophobic and Ca-unstable core, formed by $\alpha-\mathrm{CN}$ and $\beta-\mathrm{CN}$, from water and $\mathrm{Ca}$ content (Walstra, 1999). Casein subunits expression can be changed according to ruminal degradability of starch and protein (Li et al., 2015), which is associated with energy and AA (from the microbial protein or RUP proportion) availability for milk synthesis.

Previous studies also reported that ruminal (Fischer et al., 2012) and blood (Martins et al., 2015) acidification were also associated with milk instability due to the higher blood and milk concentration of iCa as a response to compensate for blood acidification. Therefore, both nutrient deficiency and its excess due to higher NFC sources (resulting in ruminal acidosis) may be associated with unstable milk. However, it is still unknown if milk instability can occur only as a consequence of casein subunit proportion changes or if iCa concentration must be increased to reduce MES. Thus, it has not been determined whether both nutrient deficiency and blood acidification change milk stability in the same way. Previous studies observed that corn processing, such as ensiling high-moisture corn or steam-flaking, may increase starch digestibility, as well as propionic acid and microbial protein production, and, consequently, energy and AA availability for milk synthesis (Oba and Allen, 2003; Vaz Pires et al., 2008; Carmo et al., 2015). However, excess rumen-digestible starch can increase the risk of ruminal acidosis, reducing lactation performance (Carmo et al., 2015) and milk stability (Fischer et al., 2012; Martins et al., 2015).

The CP degradability can also determine microbial protein yield, and RDP and RUP levels need to be adjusted to meet the microbial nitrogen and AA requirements of the cow. Previous studies reported the effect of corn processing and CP degradability on lactation performance and efficiency of $\mathrm{N}$ utilization (Miyaji et al., 2014; Savari et al., 2018). However, it is still unclear what the optimal RDP and RUP levels are according to the carbohydrates sources of the diet, which must meet $\mathrm{N}$ and $\mathrm{AA}$ requirements for microbial growth, optimizing $\mathrm{N}$ utilization and cow performance (White et al., 2017) and providing milk protein stability for the dairy industry.
In the present study, we hypothesized that steamflaked corn (SFC) has higher starch digestibility compared with ground corn (GC) and, consequently, results in more energy for milk synthesis. However, SFC diets increase ruminal acidification and milk iCa concentration, which reduce MES and milk heat coagulation time (HCT) at $140^{\circ} \mathrm{C}$. Moreover, RDP and RUP levels to optimize lactation performance, efficiency of $\mathrm{N}$ utilization, and milk composition and stability depend on corn processing. To test these hypotheses, the present study aimed to evaluate the effect of corn processing and $\mathrm{CP}$ degradability on digestive metabolism, lactation performance, and milk composition and stability of lactating dairy cows.

\section{MATERIALS AND METHODS}

\section{Experimental Design and Animals}

The present study was conducted with the approval of the Ethics Committee on Animal Use of the School of Veterinary Medicine and Animal Science, with protocol number CEUA 8085081015. The present protocol is in accordance with the rules issued by the National Council for Control of Animal Experimentation (CONCEA; Brazil, 2009) and with the Law 11.794 of October 8, 2008, Decree 6899, issued July 15, 2009.

At the beginning of the study, 20 Holstein cows with an average of $162 \pm 70 \mathrm{DIM}, 666 \pm 7 \mathrm{~kg}$ of BW, and $36 \pm 7.8 \mathrm{~kg} / \mathrm{d}$ of milk yield (MY) were distributed in a Latin square design, with 5 contemporaneous balanced squares, 4 periods of $21 \mathrm{~d}$, and 4 treatments (factorial arrangement $2 \times 2$ ). Factor 1 was corn processing (GC ground through a 2-mm screen, averaging $952 \pm$ $1.86 \mu \mathrm{m}$ particle size, or SFC at $280 \mathrm{~g} / \mathrm{L}$ ), and factor 2 was CP degradability (high $=107 \mathrm{~g}$ of $\mathrm{RDP} / \mathrm{kg}$ of $\mathrm{DM}$ and $51 \mathrm{~g}$ of RUP $/ \mathrm{kg}$ of DM; low $=95 \mathrm{~g}$ of RDP/ $\mathrm{kg}$ of $\mathrm{DM}$ and $63 \mathrm{~g}$ of $\mathrm{RDP} / \mathrm{kg}$ of $\mathrm{DM})$. To reduce CP degradability, solvent-extracted soybean meal (SESM) and urea were partial replaced by heat-treated soybean meal (HTSM; SoyPass, Cargill, Uberlandia, Brazil). The GC particle size was measured using sieves of $3,350,2,360,1,700,1,180,1,000$, and $420 \mu \mathrm{m}$ and calculations were made using a log distribution (Baker and Herrman, 2002). For SFC processing, the roller tension and distance as well as steaming time were adjusted to produce a flake density of $280 \mathrm{~g} / \mathrm{L}$, as measured after processing.

The first $14 \mathrm{~d}$ were designated as diet adaptation and the last $7 \mathrm{~d}$ were for sampling. Diets were based on corn silage as the sole forage source, at $49.5 \%$ of diet DM, along with SESM, urea, whole raw soybean, citrus pulp pellets, GC, SFC, mineral-vitamin supplement, and HTSM (Table 1). Diets were offered ad libitum (offered 
Table 1. Ingredient proportion and chemical composition of experimental diets with different corn processing and $\mathrm{CP}$ degradability fed to lactating dairy cows

\begin{tabular}{|c|c|c|c|c|}
\hline \multirow[b]{2}{*}{ Item } & \multicolumn{2}{|c|}{$\mathrm{SFC}^{1}$} & \multicolumn{2}{|c|}{$\mathrm{GC}^{2}$} \\
\hline & $\mathrm{HCPD}^{3}$ & $\mathrm{LCPD}^{4}$ & HCPD & LCPD \\
\hline \multicolumn{5}{|l|}{ Ingredient, $\mathrm{g} / \mathrm{kg}$ of $\mathrm{DM}$} \\
\hline Corn silage & 495 & 495 & 495 & 495 \\
\hline $\mathrm{GC}$ & - & - & 212 & 212 \\
\hline SFC & 212 & 212 & - & - \\
\hline SESM $^{5}$ & 103 & 91.9 & 103 & 91.9 \\
\hline $\mathrm{HTSM}^{6}$ & 0 & 44.7 & 0 & 44.7 \\
\hline Whole soybean & 66.9 & 66.9 & 66.9 & 66.9 \\
\hline Urea & 7.8 & 2.8 & 7.8 & 2.8 \\
\hline Citrus pulp & 84.3 & 56.3 & 84.3 & 56.3 \\
\hline Dicalcium phosphate & 2.8 & 2.8 & 2.8 & 2.8 \\
\hline Na bicarbonate & 8 & 8 & 8 & 8 \\
\hline $\mathrm{NaCl}$ & 3.1 & 3.1 & 3.1 & 3.1 \\
\hline Magnesium oxide & 1.9 & 1.9 & 1.9 & 1.9 \\
\hline Mineral-vitamin mixture ${ }^{7}$ & 15.1 & 15.1 & 15.1 & 15.1 \\
\hline \multicolumn{5}{|c|}{ Chemical composition, g/kg of DM (unless noted) } \\
\hline DM & 541 & 555 & 544 & 534 \\
\hline Starch & 261 & 261 & 264 & 264 \\
\hline $\mathrm{CP}$ & 158 & 157 & 159 & 160 \\
\hline RDP & 107 & 94.2 & 107 & 96 \\
\hline RUP & 51 & 62.8 & 52 & 64 \\
\hline $\mathrm{MP}^{8}$ & 105 & 115 & 105 & 115 \\
\hline RDP ruminal balance ${ }^{8} \mathrm{~g} / \mathrm{d}$ & 186 & -75 & 191 & -69 \\
\hline NDF & 356 & 353 & 352 & 349 \\
\hline $\mathrm{NDF}^{9}$ & 302 & 300 & 299 & 297 \\
\hline $\mathrm{ADF}$ & 231 & 229 & 228 & 227 \\
\hline $\mathrm{NDFCP}^{10}$ & 19.3 & 27.9 & 19.3 & 27.9 \\
\hline $\mathrm{ADFCP}^{11}$ & 9.87 & 10.6 & 9.87 & 10.6 \\
\hline $\mathrm{TDN}^{8}$ & 692 & 695 & 690 & 694 \\
\hline $\mathrm{NE}_{\mathrm{L}},{ }^{8} \mathrm{Mcal} / \mathrm{kg}$ & 1.60 & 1.61 & 1.59 & 1.60 \\
\hline Ether extract & 30 & 31 & 29 & 30 \\
\hline Lignin & 56 & 59 & 57 & 60 \\
\hline
\end{tabular}

${ }^{1} \mathrm{SFC}=$ steam-flaked corn $(7$-h in vitro starch disappearance $=40.5 \%$ of total starch).

${ }^{2} \mathrm{GC}=$ ground corn $(7-\mathrm{h}$ in vitro starch disappearance $=31.4 \%$ of total starch).

${ }^{3} \mathrm{HCPD}=$ high CP degradability: $107 \mathrm{~g}$ of RDP $/ \mathrm{kg}$ of DM and $51 \mathrm{~g}$ of RUP $/ \mathrm{kg}$ of DM.

${ }^{4} \mathrm{LCPD}=$ low $\mathrm{CP}$ degradability: $95 \mathrm{~g}$ of $\mathrm{RDP} / \mathrm{kg}$ of $\mathrm{DM}$ and $63 \mathrm{~g}$ of $\mathrm{RUP} / \mathrm{kg}$ of DM.

${ }^{5} \mathrm{CP}$ degradability of solvent-extracted soybean meal (SESM) $=68 \%$ of RDP and $32 \%$ of RUP $(\% \mathrm{CP})$.

${ }^{6} \mathrm{CP}$ degradability of heat-treated soybean meal $(\mathrm{HTSM})=31 \%$ of RDP and $69 \%$ of RUP $(\% \mathrm{CP})$.

${ }^{7}$ Mineral mixture composition per kilogram: $242 \mathrm{~g}$ of Ca [minimum (min)], $30 \mathrm{mg}$ of Co (min), 1,008 $\mathrm{mg}$ of $\mathrm{Cu}$ (min), $80 \mathrm{~g}$ of S (min), $390 \mathrm{mg}$ of Fl (maximum), $39 \mathrm{~g}$ of P (min), $60 \mathrm{mg}$ of I (min), $20 \mathrm{~g}$ of $\mathrm{Mg}(\mathrm{min}), 2,998$ $\mathrm{mg}$ of $\mathrm{Mn}(\mathrm{min}), 1,100 \mathrm{mg}$ of monensin sodium (min), $30 \mathrm{mg}$ of Se (min), 4,032 $\mathrm{mg}$ of Zn (min), 400,000 IU of vitamin $\mathrm{A}(\mathrm{min}), 40,000 \mathrm{IU}$ of vitamin $\mathrm{D}_{3}(\mathrm{~min})$, and 1,450 IU of vitamin $\mathrm{E}(\mathrm{min})$.

${ }^{8}$ Estimated by NRC (2001).

${ }^{9} \mathrm{NDF}_{\mathrm{pe}}=\mathrm{NDF} \times \%$ particles retained on the 4-mm screen of the Penn State particle size separator (Maulfair and Heinrichs, 2012).

${ }^{10} \mathrm{NDFCP}=$ neutral detergent insoluble $\mathrm{CP}$.

${ }^{11} \mathrm{ADFCP}=$ acid detergent insoluble $\mathrm{CP}$

to allow 5 to $10 \%$ of refusals) as TMR and were balanced to meet or exceed nutritional requirements based on NRC (2001), except low CP degradability that was balanced to meet MP requirements but not to meet the ruminal protein balance $(\mathrm{RDP}$ balance $=-75 \mathrm{~g} / \mathrm{d}$ ) according to NRC (2001).

Throughout the experiment, cows were housed in individual pens $\left(17.5 \mathrm{~m}^{2}\right)$ in a freestall system with sand bedding and forced ventilation, fed twice daily (0800 and $1300 \mathrm{~h}$ ) in individual bunks, and milked twice daily (0600 and $1600 \mathrm{~h}$ ). Body weight was evaluated on d 21 of each period.

\section{In Vitro Assay for 7-h Starch Disappearance}

Seven-hour in vitro starch disappearance of GC and SFC was determined by a digestibility assay using an Ankom Ruminal Fermenter (Daisy-II Fermenter An- 
kom Technology Corp., Fairport, NY). First, samples were ground through a 1-mm screen and submitted to chemical analysis to determine the starch content (Ehrman, 1996). Samples of GC and SFC were weighed $(0.5 \mathrm{~g})$ in F57 digestion bags (Ankom Technology Corp.), sealed, and then put into the digestion vessel with preheated $\left(39^{\circ} \mathrm{C}\right)$ buffer (McDougall, 1948) and gassed with $\mathrm{CO}_{2}$. Ruminal fluid inoculum was obtained from a rumen-cannulated lactating Holstein fed a TMR diet ( $70 \%$ forage and 30\% concentrate) based on corn silage, ground corn, SESM, urea, and mineral-vitamin mixture. Ruminal contents were squeezed through 4 cheesecloth layers into a prewarmed insulated bottle, and then strained again through cheesecloth into separatory funnels gassed with $\mathrm{CO}_{2}$ and placed in a $39^{\circ} \mathrm{C}$ water bath for $20 \mathrm{~min}$ to remove floating materials. $\mathrm{Ru}-$ minal inoculum was combined with buffer and samples and were incubated for $7 \mathrm{~h}$. After incubation, samples were washed with cold tap water until water was clear; samples were then dried at $55^{\circ} \mathrm{C}$ for $72 \mathrm{~h}$. Starch content in the residual of incubation was determined according to Ehrman (1996).

\section{In Situ Assay for Protein Fraction Determination}

The protein fractions (A, B, and $\mathrm{C}$ ) and degradation rate of SESM and HTSM were estimated using an in situ assay (Ørskov and McDonald, 1979) to assist in balancing the diets for RDP and RUP levels. Polyester bags $(10 \times 19 \mathrm{~cm}$ with $50 \mu \mathrm{m}$ porosity; Foraging Bag, Ankom) were dried overnight at $55^{\circ} \mathrm{C}$ and placed in a desiccator for 30 min before weighing dried bags and recording weights. Five grams of each ingredient were weighed in a different bag and incubated in duplicate in 2 lactating dairy cows according to the following incubation times: $0,1.5,3,6,12,24$, and $48 \mathrm{~h}$. The 0 -h bags were washed in the same way as bags incubated in the rumen for the other time points but were not incubated. Two empty bags (blank) were incubated at each time point to determine any residual $\mathrm{N}$ after the incubation, cleaning, and drying processes; the results were considered for a correction of $\mathrm{N}$ degradation estimation. After each incubation time point, all bags were washed with tap water until the water was clear. After washing, bags were dried at $55^{\circ} \mathrm{C}$ for $72 \mathrm{~h}$ and weighed. The CP content was estimated by method 990.03 of AOAC International $(2000 ; \mathrm{N} \times 6.25)$. Fractions A and $\mathrm{B}$ and rate of degradation $(\mathrm{kd})$ were calculated by fitting ruminal $\mathrm{N}$ degradation versus time using an exponential equation, and fraction $\mathrm{C}$ was calculated as $1-(\mathrm{A}+\mathrm{B})$ (Ørskov and McDonald, 1979). The RDP and RUP were estimated from A, B, C, and passage rate $(\mathrm{kp})$ at $0.08 / \mathrm{h}$, according to NRC (2001):

$$
\begin{gathered}
\mathrm{RDP}=\mathrm{A}+\mathrm{B} \times[\mathrm{kd} /(\mathrm{kd}+\mathrm{kp})], \text { and } \\
\mathrm{RUP}=\mathrm{C}+\mathrm{B} \times[\mathrm{kp} /(\mathrm{kd}+\mathrm{kp})] .
\end{gathered}
$$

\section{Feed, Refusals, Urine, and Fecal Sampling}

During the first $4 \mathrm{~d}$ of each sampling period, samples of ingredients and individual refusals were collected and frozen at $-20^{\circ} \mathrm{C}$ until laboratory analysis. Fecal (directly from the rectum) and urine (by vulva massage) samples were collected at 9-h intervals during the first $3 \mathrm{~d}$ of each sampling period (Harvatine and Allen, 2006): d 1 sampling at 0900 and $1800 \mathrm{~h}$; d 2 sampling at 0300, 1200, and $2100 \mathrm{~h}$; and d 3 sampling at 0600, 1500, and $0000 \mathrm{~h}$. Approximately $0.5 \mathrm{~kg}$ of feces was taken at each sampling and frozen at $-20^{\circ} \mathrm{C}$ until laboratory analysis. Approximately $200 \mathrm{~mL}$ of urine were sampled and immediately a subsample of $20 \mathrm{~mL}$ was diluted in $80 \mathrm{~mL}$ of sulfuric acid $0.036 \mathrm{~N}$ and frozen at $-20^{\circ} \mathrm{C}$.

\section{Chemical Analysis}

Feed, refusals, and fecal samples were thawed at room temperature, composited, and predried at $65^{\circ} \mathrm{C}$ for $72 \mathrm{~h}$. After drying, samples were ground through a 1-mm screen before being submitted to analyses. We used the methods of AOAC International (2000) to determine DM (method 930.15), ash (method 942.05), ether extract (EE; method 920.39), and $\mathrm{CP}(\mathrm{N} \times 6.25$; method 990.03); starch was determined via the method of Ehrman (1996); and NDF, using a-amylase without addition of $\mathrm{Na}$ sulfite, and ADF were determined according to Mertens (2002). Additionally, neutral detergent insoluble $\mathrm{N}$, acid detergent insoluble $\mathrm{N}$, and ADL were determined according to Van Soest et al. (1991). Based on the nutrient content of feed and refusals, DM and nutrient intake (CP, NDF, EE, and starch) were calculated.

\section{Total Apparent Digestibility}

Total fecal excretion was estimated using indigestible NDF as an internal marker. Feed, refusals, and fecal samples were predried at $65^{\circ} \mathrm{C}$ for $72 \mathrm{~h}$ and ground through a $2-\mathrm{mm}$ screen. Samples were incubated in bags manually made with nonwoven tissue $\left(100 \mathrm{~g} / \mathrm{m}^{2}\right.$; $5 \times 5 \mathrm{~cm}$ ) at $20 \mathrm{mg}$ of sample $/ \mathrm{cm}^{2}$ of bag (Kuwahara et al., 2015). Bags were incubated for $288 \mathrm{~h}$ in the rumen of 2 Holstein cows that were fed a TMR diet containing $70 \%$ forage and $30 \%$ concentrate, based on corn silage, ground corn, SESM, urea, and mineral-vitamin mixture (Casali et al., 2008). After incubation, bags were washed with tap water until the water ran clear and submitted 
to determination of NDF using Na sulfite. Fecal excretion was estimated based on indigestible NDF intake and its concentration in feces samples, as well as totaltract apparent digestibility of DM and nutrients, where the nutrient intake and excretion (nutrient content in fecal samples $\times$ total fecal excretion) were estimated.

\section{N Productive Efficiency and Purine Derivative:Creatinine Index}

The $\mathrm{N}$ productive efficiency was calculated by dividing the $\mathrm{N}$ secreted in milk ( $\mathrm{N} \%$ vs. $\mathrm{MY} ; \mathrm{kg} / \mathrm{d}$ ) by the $\mathrm{N}$ intake. Urine samples were thawed at room temperature for determination of concentration of allantoin and uric acid using colorimetric commercially available kits and a semiautomatic biochemical analyzer (Bioclin 100, Belo Horizonte, MG, Brazil; Oliveira et al., 2001). Milk was sampled at third and fourth day of the sampling period and frozen at $-20^{\circ} \mathrm{C}$. Milk concentrations of allantoin were determined using colorimetric commercially available kits and a semiautomatic biochemical analyzer (Bioclin 100; Oliveira et al., 2001). Total purine derivatives (PD) were obtained by the sum of urinary concentration of allantoin and uric acid and milk concentration of allantoin. Creatinine concentration was estimated using colorimetric commercial kits with a semi-automatic biochemical analyzer (Bioclin 100). The PD:creatinine index (indicative of ruminal microbial flow) was calculated as PD (molar concentration)/creatinine (molar concentration) $\times \mathrm{BW}^{0.75}$ (Orellana et al., 2004). The PD:digestible DMI index (indicative of efficiency of ruminal microbial flow) was calculated by dividing PD (mmol/L) by digestible DMI (DMI vs. DM digestibility coefficient).

\section{Milk Yield, Composition, and Stability}

Milk yield was weighed by electronic sampler (DeLaval, Campinas, SP, Brazil) from d 15 to 21 of each period. Milk yield was corrected to $3.5 \%$ FCM according to NRC (2001). Milk was sampled through the first $3 \mathrm{~d}$ of sampling period, chilled, and preserved with 2-bromo2-nitropropane-1,3-diol $(0.05 \%$, wt/vol $)$ for determination of fat, lactose, TS, casein, and CP by infrared absorption (Bentley 2000, Bentley Instruments, Chaska, MN), and MUN by Fourier transform infrared spectroscopy (MilkoScan 6000 FT+, Foss Analytical, Hillerød, Denmark). Milk SCC was determined by flow cytometry (Somacount 300, Bentley Instruments). Solids-not-fat were estimated by the difference between TS and fat content.

Over the first $2 \mathrm{~d}$ of the sampling period, milk was sampled and stored in plastic bottles $(100 \mathrm{~mL})$ without lids at $5^{\circ} \mathrm{C}$ for $24 \mathrm{~h}$ to release dissolved $\mathrm{CO}_{2}$. The iCa concentration was determined using a potentiometer (Orion Star A2140 pH/ISE, Thermo Fisher Scientific, Chelmsford, MA) with a selective probe (Orion 9720BN, Thermo Fisher Scientific) and pH by potentiometry (Barros et al., 1999). The MES analysis was performed at room temperature by mixing $2 \mathrm{~mL}$ of milk and $2 \mathrm{~mL}$ of ethanolic solutions at ethanol concentrations of $68,70,72,74,76,78,80,82$, and $84 \%$ (vol/vol) (Zanela et al., 2006). The MES results were defined as the lowest ethanol concentration in which coagulation of milk samples occurred. The $\mathrm{HCT}$ at $140^{\circ} \mathrm{C}$ was assessed by determination of coagulation time using glass capillaries $(7.00-\mathrm{cm}$ long, $0.15-\mathrm{cm}$ external diameter, and $0.1-\mathrm{cm}$ internal diameter), individually filled with milk sample, heat sealed, and submitted to immersion in glycerin at $140^{\circ} \mathrm{C}$. The $\mathrm{HCT}$ was determined as the time taken for the milk samples coagulation (Negri et al., 2003).

\section{Casein Subunits and Whey Proteins}

Milk was sampled on the third and fourth day of the sampling period and frozen at $-20^{\circ} \mathrm{C}$. Separation and identification of casein subunits $(\alpha-\mathrm{CN}, \beta-\mathrm{CN}$, and $\kappa-\mathrm{CN})$ and whey proteins $(\alpha-\mathrm{LA}$ and $\beta-\mathrm{LG})$ was performed at $220 \mathrm{~nm}$ in an HPLC system (Shimadzu, Kyoto, Japan) equipped with UV detector and Jupiter C18 column $(4 \mu \mathrm{m}, 4.6 \times 150 \mathrm{~mm}$; Phenomenex, Torrance, CA; Bobe et al., 1998). Chromatographic run was carried out using mobile phases solvent A (acetonitrile: water:trifluoroacetic acid at 100:900:1, respectively) and solvent B (acetonitrile:water:trifluoroacetic acid at 900:100:1, respectively) at room temperature. The gradient program started with $25 \%$ of solvent B and the proportion of solvent was gradually increased after injection of the sample - 34\% (at $4 \mathrm{~min}$ ), $48 \%$ (at 11 $\mathrm{min}$ ), $50 \%$ (at $13 \mathrm{~min}$ ), and $100 \%$ (at $17 \mathrm{~min}$ )-before returning to the initial conditions after 2 min. Flow rate was $1.0 \mathrm{~mL} / \mathrm{min}$ (Oliveira et al., 2011). Purified $\alpha_{S^{-}}, \beta-$, and $\kappa-C N, \alpha-L A$, and $\beta-L G$ standards (Sigma, St. Louis, MO) were diluted in distilled water, and aliquots were frozen at $-20^{\circ} \mathrm{C}$.

Individual protein standards were prepared exactly as described for milk samples at the following concentrations: $\alpha_{S^{-}} \mathrm{CN}=0.5,1.0,2.0$, and $4.0 \mathrm{mg} / \mathrm{mL} ; \beta-\mathrm{CN}$ $=0.375,0.75,1.50$, and $3.0 \mathrm{mg} / \mathrm{mL} ; \kappa-\mathrm{CN}=0.187$, $0.375,0.75$, and $1.50 \mathrm{mg} / \mathrm{mL} ; \alpha-\mathrm{LA}=0.125,0.250$, 0.375 , and $0.5 \mathrm{mg} / \mathrm{mL}$; and $\beta-\mathrm{LG}=0.25,0.5,0.75$ and $1.0 \mathrm{mg} / \mathrm{mL}$. A simple regression equation for each protein standard was performed and the calibration curve was plotted against the measured peak areas of the samples to quantify casein subunits $\left(\alpha_{\mathrm{S1}^{-}}, \alpha_{\mathrm{S} 2^{-}}, \beta-\right.$, and $\kappa-\mathrm{CN})$ and whey proteins. Retention times for $\alpha_{S^{-}}, \beta-$, and $\kappa-\mathrm{CN}, \alpha-\mathrm{LA}$, and $\beta-\mathrm{LG}$, respectively, were 12.3 , 
$12.9,9.1,14.4$, and $14.1 \mathrm{~min}$. The ratio of $\alpha_{\mathrm{S}_{1}} \mathrm{CN}$ to $\alpha_{\mathrm{S}_{2}}$ CN was assumed to be 4:1 (wt/wt; Bobe et al., 1998). The $\mathrm{k}$-CN standard was identified in 3 consecutive peaks areas, which, according to Bobe et al. (1998), were $\kappa$-CN 1,2 , and $3(1=\kappa$-CN glycosylated; $2=$ $\kappa$-CN unglycosylated genetic variant $\mathrm{A} ; 3=\kappa-\mathrm{CN}$ unglycosylated genetic variant B). Thus, total $\kappa-\mathrm{CN}$ was estimated as the sum of the 3 peak areas identified by the $\kappa$-CN standard, glycosylated $\kappa-\mathrm{CN}$ content was calculated as the peak area of $\kappa-\mathrm{CN} 1$, and unglycosylated $\kappa$-CN content was calculated as the sum of peak areas of $\kappa-\mathrm{CN} 2$ and 3.

\section{Blood Sampling and Analysis}

On the first day of the sampling period, blood was sampled from the tail vein or artery before feeding at $0500 \mathrm{~h}$. A second blood sample was taken $4 \mathrm{~h}$ after morning feeding $(0900 \mathrm{~h})$ for the determination of blood urea concentration. Blood samples were collected using tubes without anticoagulant (BD Vacutainer Plus Plastic Serum Tubes, Franklin Lakes, NJ) and tubes containing glycolytic inhibitor for glucose determination (BD Vacutainer Fluoride Tubes) and immediately centrifuged at $1,006 \times g$ at $4^{\circ} \mathrm{C}$ for $15 \mathrm{~min}$. The serum was stored at $-20^{\circ} \mathrm{C}$ until analysis. Serum total proteins, albumin, glucose, urea, aspartate aminotransferase and $\gamma$-glutamyltransferase enzymes, $\mathrm{Ca}$, and $\mathrm{iCa}$ were estimated by colorimetric commercial kits in a semi-automatic biochemical analyzer (Bioclin 100).

\section{Statistical Analysis}

Data were analyzed using SAS software (version 9.2, SAS Institute Inc., Cary, NC) after checking for residuals normality and variance homogeneity. The MIXED procedure of SAS was used for data analysis according to the following model:

$$
\begin{aligned}
\mathrm{Y}_{\mathrm{ijklm}}=\mu & +\operatorname{Corn}_{\mathrm{i}}+\operatorname{CPdeg}_{\mathrm{j}}+\left(\operatorname{Corn}_{\mathrm{i}} \times \operatorname{CPdeg}_{\mathrm{j}}\right) \\
& +\mathrm{S}_{\mathrm{k}}+\mathrm{C}_{\mathrm{l}(\mathrm{k})}+\mathrm{P}_{\mathrm{m}}+\mathrm{e}_{\mathrm{ijk} \mathrm{k} \mathrm{m}},
\end{aligned}
$$

where $\mathrm{Y}_{\mathrm{ijk} k \mathrm{~m}}=$ dependent variable; $\mu=$ overall mean; Corn $_{\mathrm{i}}=$ fixed effect of corn processing i $(1 \mathrm{df}) ;$ CPdeg $_{\mathrm{j}}$ $=$ fixed effect of $\mathrm{CP}$ degradability $(1 \mathrm{df}) ; \mathrm{Corn}_{\mathrm{i}} \times \mathrm{CP}-$ $\operatorname{deg}_{\mathrm{j}}=$ fixed effect of interaction between $\operatorname{Corn}_{\mathrm{i}}$ and CPdeg $_{\mathrm{j}}(1 \mathrm{df}) ; \mathrm{S}_{\mathrm{k}}=$ fixed effect of Latin square $\mathrm{k}[1$ to $5(4 \mathrm{df})] ; \mathrm{C}_{\mathrm{l}(\mathrm{k})}=$ random effect of cow 1 within each Latin square $[1=1$ to $20(15 \mathrm{df})] ; \mathrm{P}_{\mathrm{m}}=$ fixed effect of period $\mathrm{m}$ [1 to 4 (3 df)]; and $\mathrm{e}_{\mathrm{ijklm}}=$ random error associated with each observation. Degrees of freedom were calculated according to the Satterthwaite method (Fai and Cornelius, 1996). Least squares means esti- mates were reported and their comparison $(\alpha=0.05)$ was performed using DIFF option of the LSMEANS statement. For all statistical analyses, significance was declared at $P \leq 0.05$ and trends at $P \leq 0.10$.

\section{RESULTS}

The experimental diets had $160 \mathrm{~g} / \mathrm{kg}$ of CP, $260 \mathrm{~g} /$ $\mathrm{kg}$ of starch, and $350 \mathrm{~g} / \mathrm{kg}$ of NDF, but the 7 -h in vitro starch disappearance of SFC was $29 \%$ higher than GC samples (31.4 and 40,5\% of total starch, respectively). High-CP degradability diets had a positive estimated RDP ruminal balance (around $188 \mathrm{~g} / \mathrm{d}$ ) and MP of 105 $\mathrm{g} / \mathrm{kg}$ of DM, whereas low-CP degradability diets had negative estimated RDP ruminal balance (around -72 $\mathrm{g} / \mathrm{d}$ ) and MP of $115 \mathrm{~g} / \mathrm{kg}$ of DM. A significant interaction was observed between corn processing and CP degradability on DMI $(P=0.007)$, MY $(P=0.042)$, and HCT $(P=0.029)$. When cows were fed GC diets and low CP degradability, DMI was increased by 1.73 $\mathrm{kg} / \mathrm{d}, \mathrm{MY}$ by $2.3 \mathrm{~kg} / \mathrm{d}$, and HCT by $4.8 \mathrm{~min}$ compared with cows fed GC and high CP degradability. However, we observed no effect of RDP-to-RUP ratio and SFC diets on DMI, MY, and HCT. We noted an effect of corn processing on total apparent digestibility, considering that cows fed SFC diets had higher DM, starch, $\mathrm{CP}$, and EE digestibility than cows fed GC diets. We found an interaction between CP degradability and corn processing on total apparent NDF digestibility, as it was reduced when cows were fed GC and low CP degradability compared with other diets $(P=0.041)$. No interaction between corn processing and CP degradability was observed on FCM, and cows fed low CP degradability had higher FCM than those fed high CP degradability $(\Delta=1.36 \mathrm{~kg} / \mathrm{d} ; P=0.016)$, independent of corn processing.

Similarly to MY, we found a significant interaction between corn processing and $\mathrm{CP}$ degradability on milk lactose content and yield $(P=0.036)$. Cows fed $\mathrm{GC}$ diets had higher milk lactose content and lactose yield when fed low CP degradability, but we did not find a $\mathrm{CP}$ degradability effect on lactose content and lactose yield when cows were fed SFC diets. When cows were fed low CP degradability, they had higher milk protein content $(P=0.046)$ and milk protein yield $(P=0.025)$ than those fed high CP degradability. Additionally, cows fed low CP degradability had higher MES than those fed high CP degradability, and we observed no effect of corn processing or interaction on MES. On the other hand, we noted no effect of corn processing or $\mathrm{CP}$ degradability on milk $\mathrm{pH}$, iCa concentration, and butterfat content and yield. Milk content of TS and SNF was not affected by corn processing or CP 
degradability, but daily yield of TS $(P=0.005)$ and SNF $(P=0.004)$ was higher when cows were fed low $\mathrm{CP}$ degradability than when fed high $\mathrm{CP}$ degradability $(P=0.005$; Table 2).

We observed no interaction between CP degradability and corn processing on casein subunits and whey proteins. The $\mathrm{CP}$ degradability or corn processing did not affect milk protein content of ${\alpha s_{1}-}$ and ${\alpha s_{2}-}_{2} \mathrm{CN}$, $\kappa-\mathrm{CN}$, and $\alpha$-LA. However, when cows were fed SFC, we noted a tendency of lower content of $\beta-\mathrm{CN}(P=$ $0.093)$ and higher content of $\beta$-LG $(P=0.062)$ than when cows were fed GC diets, independent of $\mathrm{CP}$ de- gradability. When cows were fed low $\mathrm{CP}$ degradability, we found a tendency $(P=0.063)$ for higher content $(\%$ of total $\kappa-\mathrm{CN}$ content) of $\kappa-\mathrm{CN} 1$ (glycosylated $\kappa-\mathrm{CN}$ ) and lower content of $\kappa$ - $\mathrm{CN} 2$ and 3 (unglycosylated $\kappa$-CN; Table 3).

We did not observe an effect of corn processing or $\mathrm{CP}$ degradability on $\mathrm{PD}$-to-creatinine ratio; however, PD-to-digestible DMI ratio increased when cows were fed SFC compared with those fed GC diets. We found no interaction between corn processing and $\mathrm{CP}$ degradability on $\mathrm{N}$ milk secretion $(\mathrm{g} / \mathrm{d})$ and $\mathrm{N}$ productive efficiency (milk $\mathrm{N} \%$ total $\mathrm{N}$ intake). When cows were

Table 2. Effect of corn processing and CP degradability on nutrient intake and digestibility, milk yield, composition, and stability

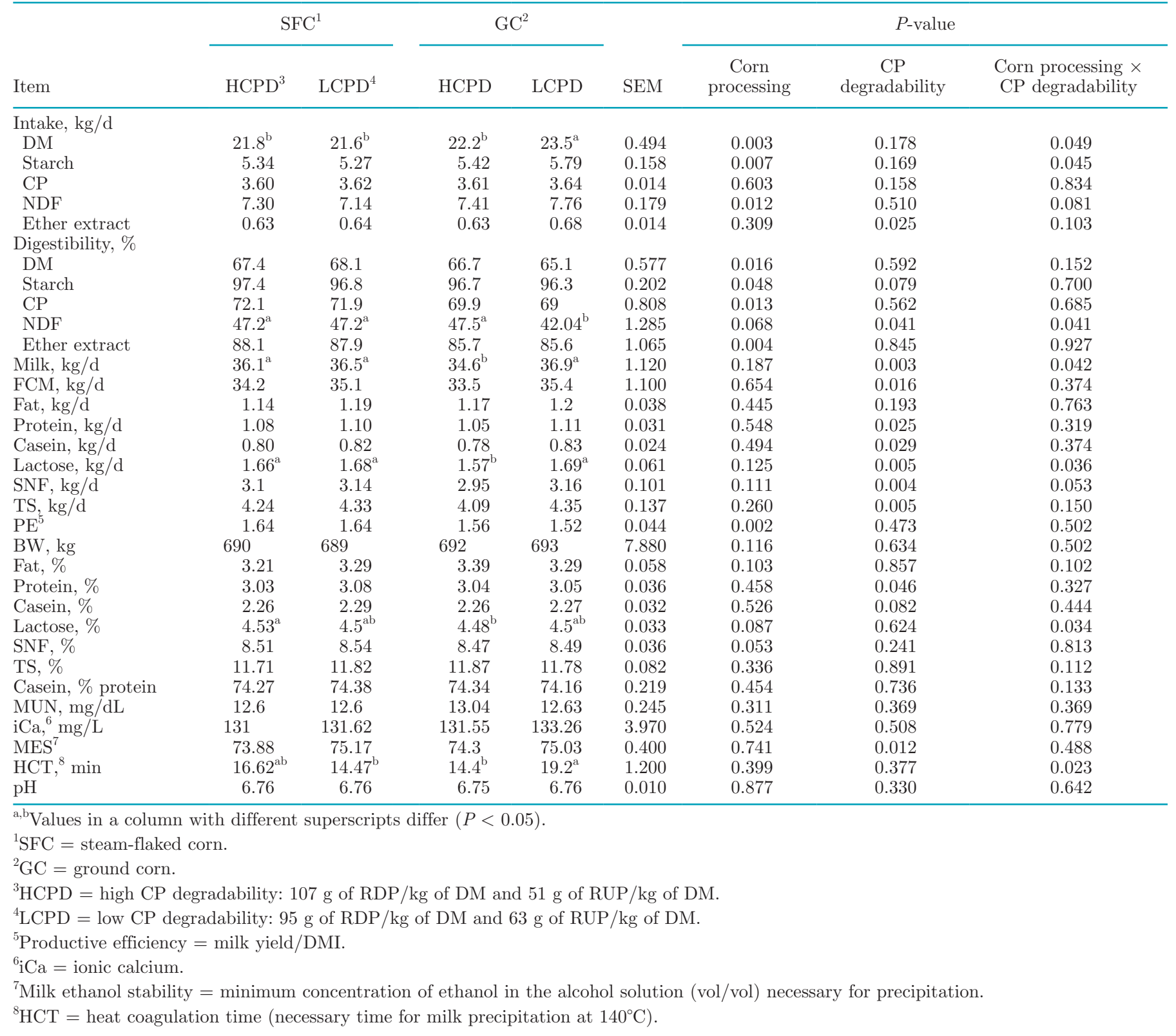


Table 3. Effect of corn processing and CP degradability on casein subunits and whey protein content

\begin{tabular}{|c|c|c|c|c|c|c|c|c|}
\hline Milk protein & \multicolumn{2}{|c|}{$\mathrm{SFC}^{1}$} & \multicolumn{2}{|c|}{$\mathrm{GC}^{2}$} & SEM & \multicolumn{3}{|c|}{$P$-value } \\
\hline$\alpha_{\mathrm{S}_{1}-\mathrm{CN}}$ & 27.0 & 27.8 & 27.9 & 28.34 & 1.57 & 0.205 & 0.206 & 0.723 \\
\hline$\alpha_{\mathrm{S} 2}-\mathrm{CN}$ & 9.0 & 9.28 & 9.29 & 9.45 & 0.526 & 0.206 & 0.206 & 0.723 \\
\hline$\beta-\mathrm{CN}$ & 30.17 & 29.17 & 30.75 & 31.77 & 1.69 & 0.093 & 0.985 & 0.283 \\
\hline$\alpha-\mathrm{LA}$ & 5.3 & 5.19 & 5.41 & 5.3 & 0.452 & 0.577 & 0.563 & 0.989 \\
\hline \multicolumn{9}{|c|}{$\%$ of total $\kappa-\mathrm{CN}^{6}$} \\
\hline$\kappa_{1}^{7}$ & 19.58 & 23.53 & 12.82 & 21.63 & 4.51 & 0.202 & 0.063 & 0.473 \\
\hline$\kappa_{2+3}{ }^{8}$ & 80.41 & 76.46 & 87.17 & 78.37 & 4.51 & 0.202 & 0.063 & 0.473 \\
\hline
\end{tabular}

${ }^{1} \mathrm{SFC}=$ steam-flaked corn.

${ }^{2} \mathrm{GC}=$ ground corn.

${ }^{3} \mathrm{HCPD}=$ high $\mathrm{CP}$ degradability: $107 \mathrm{~g}$ of RDP $/ \mathrm{kg}$ of DM and $51 \mathrm{~g}$ of RUP $/ \mathrm{kg}$ of DM.

${ }^{4} \mathrm{LCPD}=$ low $\mathrm{CP}$ degradability: $95 \mathrm{~g}$ of RDP/kg of DM and $63 \mathrm{~g}$ of RUP $/ \mathrm{kg}$ of DM.

${ }^{5} \%$ of total proteins detected by HPLC $\left(\alpha_{\mathrm{S}^{-}} \mathrm{CN}+\alpha_{\mathrm{S} 2} \mathrm{CN}+\beta-\mathrm{CN}+\kappa-\mathrm{CN}+\beta-\mathrm{LG}+\alpha-\mathrm{LA}=100 \%\right)$.

${ }^{6}$ Total $\kappa-\mathrm{CN}$ was estimated as the sum of the 3 peak areas identified by the $\kappa$ - $\mathrm{CN}$ standard.

${ }^{7} \kappa_{1}=$ glycosylated $\kappa$-CN content (calculated as the peak area of $\kappa-\mathrm{CN} 1$ ).

${ }^{8} \kappa_{2+3}=$ unglycosylated $\kappa-\mathrm{CN}$ content (calculated as the sum of peak areas of $\kappa$-CN 2 and 3 ).

fed low-CP degradability diets, higher milk secretion of $\mathrm{N}(\mathrm{g} / \mathrm{d})$ was observed as well as higher $\mathrm{N}$ productive efficiency than cows fed high-CP degradability diets (Table 4).

We observed no interaction between corn processing and CP degradability on blood metabolic outcomes. Cows fed GC had higher blood concentration of AST enzyme $(P<0.01)$ than those fed SFC, and total serum protein content increased when cows were fed low $\mathrm{CP}$ degradability compared with those fed high CP degradability (Table 5). We noted no effect of corn processing or CP degradability on blood urea concentration, but blood sampled $4 \mathrm{~h}$ after feeding had $40 \%$ more urea concentration than blood sampled immediately before feeding $(P<0.01)$.

\section{DISCUSSION}

\section{Intake and Digestibility}

The observed effects of corn processing and CP degradability on DMI, MY, and HCT were interdependent. When cows were fed SFC, CP degradability did not change DMI, MY, and heat stability; however, GC diets with low CP degradability increased those outcomes compared with high CP degradability. Previous studies reported lower DMI when starch digestibility was increased by corn processing (Allen, 2000) and by RDP inclusion, especially with the use of urea in the diet (Broderick and Reynal, 2009). In our study, it could be suggested that increasing corn starch digestibility

Table 4. Effect of corn processing and $\mathrm{CP}$ degradability on purine derivative (PD)-to-creatinine (Creat) ratio and efficiency of $\mathrm{N}$ utilization for milk production in dairy cows

\begin{tabular}{|c|c|c|c|c|c|c|c|c|}
\hline Item & \multicolumn{2}{|c|}{$\mathrm{SFC}^{1}$} & \multicolumn{2}{|c|}{$\mathrm{GC}^{2}$} & SEM & \multicolumn{3}{|c|}{$P$-value } \\
\hline PD:Creat $\times \mathrm{BW}^{0.75}$ & 355 & 353 & 347 & 337 & 14.11 & 0.508 & 0.752 & 0.824 \\
\hline PD:digestible DMI & 1.60 & 1.56 & 1.44 & 1.31 & 0.866 & 0.021 & 0.323 & 0.601 \\
\hline $\mathrm{N}$ intake, $\mathrm{g} / \mathrm{d}$ & 575.8 & 580.8 & 577.2 & 581.4 & 3.048 & 0.709 & 0.100 & 0.884 \\
\hline
\end{tabular}

${ }^{1} \mathrm{SFC}=$ steam-flaked corn.

${ }^{2} \mathrm{GC}=$ ground corn.

${ }^{3} \mathrm{HCPD}=$ high CP degradability: $107 \mathrm{~g}$ of RDP $/ \mathrm{kg}$ of DM and $51 \mathrm{~g}$ of RUP $/ \mathrm{kg}$ of DM.

${ }^{4} \mathrm{LCPD}=$ low $\mathrm{CP}$ degradability: $95 \mathrm{~g}$ of $\mathrm{RDP} / \mathrm{kg}$ of DM and $63 \mathrm{~g}$ of RUP $/ \mathrm{kg}$ of DM. 
Table 5. Effect of corn processing and CP degradability on blood metabolic outcomes

\begin{tabular}{|c|c|c|c|c|c|c|c|c|}
\hline \multirow[b]{2}{*}{ Item } & \multicolumn{2}{|c|}{$\mathrm{SFC}^{1}$} & \multicolumn{2}{|c|}{$\mathrm{GC}^{2}$} & \multirow[b]{2}{*}{ SEM } & \multicolumn{3}{|c|}{$P$-value } \\
\hline & $\mathrm{HCPD}^{3}$ & $\mathrm{LCPD}^{4}$ & $\mathrm{HCPD}$ & LCPD & & $\begin{array}{c}\text { Corn } \\
\text { processing }\end{array}$ & $\begin{array}{c}\mathrm{CP} \\
\text { degradability }\end{array}$ & $\begin{array}{c}\text { Corn processing } \times \\
\text { CP degradability }\end{array}$ \\
\hline $\mathrm{Ca}, \mathrm{mg} / \mathrm{dL}$ & 10.6 & 10.6 & 9.46 & 9.94 & 0.649 & 0.157 & 0.741 & 0.690 \\
\hline $\mathrm{iCa},{ }^{5} \mathrm{mg} / \mathrm{dL}$ & 6.37 & 6.24 & 5.62 & 5.78 & 0.385 & 0.123 & 0.960 & 0.708 \\
\hline $\mathrm{GGT}_{2}^{6} \mathrm{U} / \mathrm{L}$ & 30.3 & 30.3 & 30.5 & 30.7 & 1.26 & 0.712 & 0.942 & 0.910 \\
\hline Albumin, g/L & 2.57 & 2.64 & 2.63 & 2.76 & 0.070 & 0.100 & 0.069 & 0.569 \\
\hline Blood urea, ${ }^{*} \mathrm{~g} / \mathrm{L}$ & & & & & & 0.587 & 0.927 & 0.188 \\
\hline $0 \mathrm{~h}^{8}$ & 32.0 & 30.5 & 30.3 & 33.2 & 0.758 & & & \\
\hline $4 \mathrm{~h}^{9}$ & 44.7 & 43.6 & 45.0 & 44.4 & 1.03 & & & \\
\hline
\end{tabular}

${ }^{1} \mathrm{SFC}=$ steam-flaked corn.

${ }^{2} \mathrm{GC}=$ ground corn.

${ }^{3} \mathrm{HCPD}=$ high $\mathrm{CP}$ degradability: $107 \mathrm{~g}$ of $\mathrm{RDP} / \mathrm{kg}$ of DM and $51 \mathrm{~g}$ of RUP $/ \mathrm{kg}$ of DM.

${ }^{4} \mathrm{LCPD}=$ low $\mathrm{CP}$ degradability: $95 \mathrm{~g}$ of RDP $/ \mathrm{kg}$ of DM and $63 \mathrm{~g}$ of RUP $/ \mathrm{kg}$ of DM.

${ }^{5} \mathrm{iCa}=$ ionic calcium.

${ }^{6} \mathrm{GGT}=\gamma$-glutamyltransferase enzyme.

${ }^{7} \mathrm{AST}=$ aspartate aminotransferase enzyme.

${ }^{8} 0 \mathrm{~h}=$ blood urea concentration before morning feeding.

${ }^{9} 4 \mathrm{~h}=$ blood urea concentration $4 \mathrm{~h}$ after morning feeding.

${ }^{*} P$-values for hour of sampling and interactions for blood urea concentration: Hour $<0.001$; Corn processing $\times$ hour $=0.994$; CP degradability $\times$ hour $=0.421$; Corn processing $\times$ CP degradability $\times$ hour $=0.319$.

by steam-flaking can reduce DMI without an effect of increased CP degradability, which suggests that a diet high in RDP can reduce DMI in diets with lower ruminal starch digestibility. Although SFC reduced DMI, we observed no effect of SFC on lactation performance compared with GC and a low-CP degradability diet, suggesting that the higher starch digestibility of SFC and the increased DMI of GC low-CP degradability diets resulted in higher lactation performance and heat stability than cows fed GC and high-CP degradability diets. On the contrary, cows fed SFC had higher productive efficiency than GC due to reduced DMI without impairing lactation performance.

The reduction of DMI with increasing starch digestibility has mostly been attributed to the higher hepatic oxidation of propionic acid (hepatic oxidation theory; Allen, 2000). In the present study, cows fed SFC had higher starch, DM, CP, and EE total-tract digestibility than those fed GC, and the 7-h in vitro starch digestibility of SFC was $29 \%$ higher than GC. Thus, the higher starch digestibility of SFC may have increased propionic acid production, resulting in lower DMI, probably due to higher flow of fuels for hepatic oxidation. In a previous study, we observed that cows fed SFC had higher ruminal propionic acid concentration than those fed GC during $16 \mathrm{~h}$ of sampling (from 0 until $16 \mathrm{~h}$ after morning feeding; Fonseca, 2018). In a previous study, the inclusion of grains with higher ruminal starch digestibility reduced DMI by $13 \%$ (Al- len, 2000) and the time spent eating by approximately 17\% (Oba and Allen, 2003).

The steam-flaking process increases the corn starch gelatinization, which results in higher rumen starch availability to the metabolism of ruminal microbes (Simas et al., 2008). Additionally, due the higher particle size of SFC, it can be retained for a longer time in the rumen for digestion than GC, which also contributed to increased rumen starch digestibility of SFC. A previous study reported an increase of $20 \%$ in ruminal starch digestibility of SFC compared with GC (Simas et al., 2008). Overall, total ruminal starch digestibility was $76.2,89.9$, and $84.8 \%$ for dry-rolled corn, high-moisture corn, and SFC, respectively (Huntington, 1997). Cooper et al. (2002) reported that ruminal starch digestibility of SFC was $19 \%$ greater than dry-rolled corn, but the total-tract starch digestibility was only $3 \%$ higher for SFC than dry-rolled corn. The rumen starch digestibility also depends on starch inclusion and on the corn kernel vitreousness, and a greater response to the steam-flaking process was observed with a highstarch diet and grains that contain a greater proportion of vitreous endosperm (Oba and Allen, 2003).

Low CP degradability increased DMI in cows fed GC diets, which could be associated with lower inclusion of urea in the diet to reduce $\mathrm{CP}$ degradability, as urea inclusion in the diet as an RDP source may reduce DMI (Broderick and Reynal, 2009). Additionally, cows fed GC with low CP degradability had lower NDF total- 
tract digestibility than those fed other diets, which can be attributed to higher DMI and, consequently, higher rumen digesta passage rate; in addition, the HTSM used in CP degradability diets had higher total (and likely undigestible) NDF content than SESM (Broderick and Reynal, 2009).

\section{PD:Creatinine Ratio and N Productive Efficiency}

We found no effect of CP degradability or interaction with corn processing on $\mathrm{PD}$-to-creatinine ratio, which suggested that low $\mathrm{CP}$ degradability $(\mathrm{RDP}=9.5 \%$ of DM) did not reduce microbial flow; however, the NRC (2001) estimated rumen $\mathrm{N}$ balance of -75 and +186 $\mathrm{g} / \mathrm{d}$ for low and high CP degradability of SFC diets, respectively. We did not collect microbial samples to correct PD-to-N ratio for more accurate estimation of microbial flow. The PD-to-N ratio can change according to the diet and animal, and even according to some laboratory modifications of PD quantifications (Firkins et al., 2006), which should be considered a limitation of our study to speculate dietary effects on rumen microbial flow.

A recent study suggested that NRC (2001) model overestimates nonmicrobial $\mathrm{N}$ flow by $18 \%$ and underestimates microbial $\mathrm{N}$ flow by $14 \%$, but both outcomes had a high variation (slope bias of $22 \%$ of root mean square error; White et al., 2017). In an attempt to achieve better estimates of microbial $\mathrm{N}$ flow, White et al. (2017) developed a new model based on postrumen appearance of feed fractions $\mathrm{A}, \mathrm{B}$, and $\mathrm{C}$, which reduced the predictive error of passage rate and digestibility rate. This new model provides better estimates (based on root mean square error and concordance correlation coefficient parameters) of diet RDP levels to optimize microbial protein synthesis (MPS) being lower than those suggested by NRC (2001; e.g., White et al., 2017). Microbial N needs to exceed $145 \%$ of RDP level to limit MPS (White et al., 2017), which is higher than the $85 \%$ proposed by NRC (2001). Although RDP level would be lower than NRC (2001) recommendation to limit MPS, these recommendations may take corn processes or ruminal digestibility and $\mathrm{N}$ balance into account for a more precise recommendation of RDP diet level to optimize MPS and minimize $\mathrm{N}$ excretion (White et al., 2017).

In our previous study (Fonseca, 2018), the ruminal concentration of $\mathrm{N}^{-\mathrm{NH}_{3}}$ verified the hypothesis that SFC diets resulted in higher ruminal utilization of $\mathrm{N}$, as cows fed SFC had lower ruminal concentration of

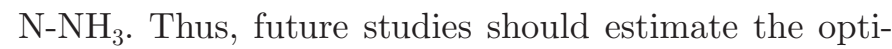
mal recommendation of RDP level for dairy cows based on corn processing (or ruminal digestibility of DM or $\mathrm{OM}$ ) and its effects on lactation performance and $\mathrm{N}$ balance. Based on our results, we would suggest that $95 \mathrm{~g}$ of $\mathrm{RDP} / \mathrm{kg}$ of DM may be sufficient for GC diets, but it is also possible to use $107 \mathrm{~g}$ of $\mathrm{RDP} / \mathrm{kg}$ of $\mathrm{DM}$ in more digestible diets (e.g., SFC) without impairing lactation performance.

We found no corn processing effect on PD-to-creatinine ratio, but $\mathrm{PD}$-to-digestible DMI ratio increased when cows were fed SFC compared with those fed GC diets, suggesting that SFC increased the efficiency of nutrients utilization by ruminal microbes. Rumendigestible OM was the main factor previously associated with MPS (Galyean and Tedeschi, 2014), although NRC (2001) estimates MPS ( $\mathrm{kg} / \mathrm{d})$ from TDN intake (MPS $=13 \%$ of TDN intake) at an adequate dietary level of RDP. Our results suggested that the inclusion of $95 \mathrm{~g} / \mathrm{kg}$ of DM of RDP and $63 \mathrm{~g} / \mathrm{kg}$ of DM of RUP did not limit the microbial flow by $\mathrm{N}$ availability and increased MP supply compared with $107 \mathrm{~g} / \mathrm{kg}$ of DM of $\mathrm{RDP}$ and $51 \mathrm{~g} / \mathrm{kg}$ of DM of RUP in both corn processing diets (GC and SFC).

Hristov et al. (2004) found no effect of RDP level on MPS when comparing 2 RDP levels (9.4 vs. $11.6 \%$; DM basis) in diets with $10.8 \% \mathrm{MP}$ as a percent of DM (CP of 15.8 vs. $18.3 \%$ ) and using $\mathrm{N}_{15}$ to estimate MPS and $\mathrm{N}$ efficiency. However, those authors found higher $\mathrm{N}$ excretion through urine and lower $\mathrm{N}$ efficiency for milk production with the higher RDP level. Milk protein proportion from MPS was not affected by RDP level and, overall, $61 \%$ of milk protein came from MPS (Hristov et al., 2004). Other studies reported that the source of RUP affected MPS, because the higher the rumen bypass proportion the more effect was observed on MPS reduction (Ipharraguerre and Clark, 2014). Those authors attributed the lower MPS with RUP sources due to lower energy and AA availability in the rumen and not because of lower total $\mathrm{N}$ availability in the rumen. Miyaji et al. (2014) reported that it is possible to increase utilization efficiency of $\mathrm{N}$ even in diets with high starch ruminal digestibility, as replacing SFC for steam-flaked rice increased efficiency of $\mathrm{N}$ utilization but reduced DMI, fiber digestibility, and lactation performance. Different from our study, Miyaji et al. (2014) used diets with $18.5 \%$ of $\mathrm{CP}$, which could have resulted in a much greater amount of $\mathrm{N}$ available for rumen microbial utilization. Although evidence exists that the recommendation of RDP level for dairy cow diets is overestimated by NRC (2001; e.g., White et al., 2017), our results agree with this hypothesis but suggest the recommendation needs to be associated with ruminal digestibility of carbohydrate sources to optimize lactation performance and reduce manure nutrient output.

Similar to our study, Savari et al. (2018) observed no effect of corn processing (SFC vs. GC) on milk N secretion and the efficiency of dietary $\mathrm{N}$ utilization for 
milk production. However, Savari et al. (2018) reported higher efficiency of dietary $\mathrm{N}$ utilization for milk production when cows were fed high CP degradability than those fed low CP degradability. This divergent result regarding RUP inclusion in the diet of lactating cows could be associated with differences in intestine digestibility of RUP source or RDP level and composition, as well as differences in corn vitreousness and ruminal digestibility.

\section{Lactation Performance}

The interaction between corn processing and CP degradability on DMI resulted in lower MY when cows were fed GC and high-CP degradability diets. Nutrient intake and its availability for milk production was probably lower for cows fed GC and high-CP degradability diets due to lower DMI compared with low CP degradability as well as lower starch, CP, and EE digestibility compared with SFC diets. Although high-CP degradability diets had lower estimated MP (NRC, 2001) than low-CP degradability diets, when cows were fed SFC diets, low CP degradability did not improve lactation performance, suggesting that the higher lactation performance of cows fed low CP degradability in GC diets was a response to higher DMI compared with high-CP degradability GC diets. However, a higher total protein and casein yield was noted with reduction of $\mathrm{CP}$ degradability, independent of corn processing, indicating higher AA supply for milk protein yield (Santos et al., 1998) with low-CP degradability diets.

Different from our study, Shen et al. (2015) reported no interaction between corn processing and CP degradability on DMI and lactation performance, and that low CP degradability reduced MPS and did not change lactation performance compared with higher $\mathrm{CP}$ degradability. The higher CP degradability evaluated by Shen et al. (2015) was equivalent to the low CP degradability of our study, suggesting that different results may be obtained depending on the RDP and RUP levels used. Savari et al. (2018) also reported no interaction between corn processing and CP degradability on lactation performance, and, contrary to our study, that cows fed diets with higher $\mathrm{CP}$ degradability produced more milk $(+1.2 \mathrm{~kg} / \mathrm{d})$ than those fed lower CP degradability. Savari et al. (2018) suggested that lower CP degradability may reduce MPS or that the RUP source used (soybean meal treated with xylose) had low intestinal digestibility, reducing the AA availability to MY. Although our data suggest that RDP and RUP levels may depend on corn processing to optimize performance, it is still unclear what the optimal RDP and RUP levels are to meet N and AA requirements for microbial growth according to carbohydrate fermentability and optimize lactation performance and $\mathrm{N}$ productive efficiency. The optimal RDP and RUP levels may depend on its levels tested, RUP and RDP source, and digestibility; therefore, testing only 2 levels of RDP and RUP is not adequate to establish the optimal ratio for GC or SFC diets.

\section{Milk Stability}

In the present study, MES increased according to the reduction of $\mathrm{CP}$ degradability. For cows fed low $\mathrm{CP}$ degradability, there may have been higher MP flow to the gut and AA availability for milk protein synthesis, especially in GC diets. Nutrient intake was the main factor positively associated with MES (Fischer et al., 2012). Previous studies evaluated the effect of feed restriction on MES and reported that cows fed restricted diets had higher milk concentration of $\mathrm{iCa}$ and lower MES (Stumpf et al., 2013). Stumpf et al. (2013) restricted $50 \%$ of DM requirements, which increased permeability of the mammary gland cell tight junctions, increasing the passage of ions, such as iCa, from blood to milk. In our study, however, we observed no effect of corn processing or CP degradability on iCa concentration. The reduction of $50 \%$ of DM offered is much more intense than the reduction of DMI observed in our study for cows fed high-CP degradability GC diets, as well as the higher energy cost to eliminate excess ammonia in the blood with high-CP degradability diets.

Blood acidification is also associated with MES, because to keep the acid-base balance requires an increase of iCa concentration as well as milk concentration of iCa (Marques et al., 2011; Martins et al., 2015). Blood acidification may occur in response to ruminal acidosis, DCAD reduction, or even the high metabolic rate or metabolic diseases of high-producing dairy cows (Fagnani et al., 2014; Martins et al., 2015). Fagnani et al. (2014) reported that $65.52 \%$ of milk samples that were ethanol unstable came from cows with metabolic disturbance, such as respiratory acidosis, metabolic acidosis, respiratory alkalosis, and metabolic alkalosis. In our study, although SFC diets had higher starch total apparent digestibility and probably higher ruminal degradability, the higher digestibility probably did not result in high enough ruminal and blood acidification to cause higher blood and milk iCa concentrations. In a previous study, corn processing and CP degradability did not change ruminal $\mathrm{pH}$ through $16 \mathrm{~h}$ of evaluation (Fonseca, 2018).

\section{Casein Subunits and Whey Proteins}

The effect of CP degradability on MES suggested that other factors not associated with iCa may affect 
MES. Changes in casein subunits proportion were associated with MES, as unstable milk samples had lower $\kappa-\mathrm{CN}$ and higher $\beta-\mathrm{CN}$ than stable samples during the ethanol test (Barbosa et al., 2012). In the casein micelle, $\mathrm{k}-\mathrm{CN}$ is located in the outer layer, as it is hydrophilic and does not react with $\mathrm{iCa}$, which plays an essential role in protecting $\alpha$ - and $\beta-\mathrm{CN}$ (hydrophobic and iCa sensible) in the micelle hydrophobic core from water contact and an iCa reaction (Walstra, 1999). Changes in casein subunit proportions or whey proteins may occur because of the quantity and quality of nutrient flow for the mammary gland due to AA availability for milk protein synthesis (Barbosa et al., 2012). We did not observe any effect of corn processing or CP degradability on $\kappa$-CN content, but cows fed SFC had higher $\beta-\mathrm{LG}$ and lower $\beta$-CN proportion (\% total milk protein) than cows fed GC diets. Additionally, cows fed low CP degradability had higher k-CN 1 (glycosylated $\kappa-\mathrm{CN}$ ) and lower $\kappa$-CN 2 and 3 (unglycosylated k-CN) than cows fed high CP degradability. $\kappa$-Casein is the only casein that can be glycosylated, usually by 3 monosaccharide (galactose, $\mathrm{N}$-acetylgalactosamine, and $\mathrm{N}$-acetylneuraminic acid) linked by threonine residues 131, 133, 135, and 136 (Fox and McSweeney, 1998). The increased glycosylated $\kappa-\mathrm{CN}$ was associated with casein micelle of lower size (Bijl et al., 2014), which had higher coagulation time and firmer clots for cheese production than casein micelles with lower glycosylated $\kappa$-CN content and casein micelles of greater size (Glantz et al., 2010).

Post-translational factors, such as nutrition and glucose metabolism in the mammary gland, altered the glycosylation rate of $\kappa$-CN. In a study using lactating mice, Lavialle and Chanat (2008) observed that lipidrestricted diets reduced the glycosylation ratio compared with regular diets. Thus, nutritional factors may determine glycosylation rate of $\kappa-\mathrm{CN}$ and, probably, casein micelle stability. Our study is the first evidence that a reduction of $\mathrm{CP}$ degradability (or increased MP supply) can increase AA availability for milk protein synthesis and the glycosylation ratio of $\kappa-\mathrm{CN}$. Although we found no interaction $(P>0.05)$ between corn processing and $\mathrm{CP}$ degradability on $\kappa-\mathrm{CN}$ glycosylation in GC diets, low CP degradability increased DMI by $1.73 \mathrm{~kg} / \mathrm{d}$ and probably increased nutrient availability for the mammary gland. Low-CP degradability diets increased $\kappa$-CN 1 proportion by $70 \%$ in GC diets and $30 \%$ in SFC diets compared with high CP degradability in both corn processing diets.

Although low CP degradability increased MES compared with high-CP degradability diets, this increase was only marginal (1 percentage unit), indicating that glycosylation of $\kappa-\mathrm{CN}$ can be an additional factor positively associated with MES but is not the main reason for unstable milk occurrence. Ionic calcium was the main milk component negatively associated with MES. The increase of iCa concentration (positive electric charges) changes the ionic balance of the casein micelle, as there is a reduction of negative charges of the casein micelle, reducing electrostatic repulsion force between them, which reduces the casein's resistance to form clots at ethanol test or heating (Barros et al., 1999).

We found no scientific results regarding an interaction between $\mathrm{iCa}$, casein subunit proportions, and glycosylation of $\kappa-\mathrm{CN}$, and it is still unknown whether these factors affect milk heat stability as they change MES. We observed a significant interaction between corn processing and CP degradability on HCT. We observed no effect of CP degradability on HCT when cows were fed SFC; however, cows fed GC diets and low CP degradability had higher HCT than cows fed GC and high CP degradability or SCF and low CP degradability. This result suggests the synchrony effect of rumen-digestible carbohydrates and $\mathrm{CP}$ degradability. The effect of CP degradability on glycosylation of $\kappa$-CN could be higher in SFC than in GC diets, probably due to the increased intake of GC and low-CP degradability diets and nutrient flow for the mammary gland. Additionally, when cows were fed SFC, they tended to have lower $\beta$-CN and higher $\beta$-LG proportion than when fed GC diets. $\beta$-Casein is hydrophobic and $\mathrm{iCa}$ sensitive; thus, a reduction of $\beta$-CN could result in a more stable casein micelle.

Previous studies indicated that severe feed restriction (Barbosa et al., 2012) and blood acidification (Marques et al., 2011; Martins et al., 2015) increased milk iCa concentration, which reduced milk stability at MES and heating at $140^{\circ} \mathrm{C}$. Barbosa et al. (2012) and Martins et al. (2015) reported changes of $\mathrm{iCa}$ and casein subunit concentrations, although the contribution of each of these factors on the reduction of casein micelle stability remains to be determined. In the present work, no effect of corn processing or CP degradability on iCa was observed, and the increase of MES with a reduction of CP degradability was attributed to glycosylation of $\kappa-C N$. Several factors may reduce MES, and future studies should establish programs of prevention and control of unstable milk during the ethanol test in countries that still use MES as the first milk quality onfarm screening test. Meeting nutritional requirements is the first priority to prevent ethanol-unstable nonacidic milk (Barbosa et al., 2012; Fischer et al., 2012; Stumpf et al., 2013). In addition, prevention of ruminal and blood acidification (Marques et al., 2011; Martins et 
al., 2015) and optimization of nutrient utilization and $\mathrm{CP}$ degradability may contribute to the improvement of milk stability.

\section{CONCLUSIONS}

The effects of corn processing and CP degradability on DMI, MY, and milk HCT are interdependent. Crude protein degradability does not change DMI, MY, and milk HCT when cows are fed SFC diets, but low CP degradability increased DMI, MY, and milk HCT for cows fed GC diets. Overall, low CP degradability increases MES, as well as daily yield of milk protein, casein, and the proportion of $\kappa-\mathrm{CN} 1$ (glycosylated $\kappa-\mathrm{CN}$ ). On the other hand, SFC diets reduced $\beta-\mathrm{CN}$ proportion compared with GC diets. Our results suggest that changes in milk protein composition can change MES and milk $\mathrm{HCT}$, probably as a response to nutrient flow and their quality to milk yield (e.g., AA availability for milk protein synthesis). The use of SFC diets increases total apparent digestibility of DM, starch, $\mathrm{CP}$, and EE, as well as the efficiency of $\mathrm{N}$ utilization for milk production. Thus, CP degradability recommendations of diets may depend on starch source and its ruminal availability, and nutritional models should take corn processing into account (or even total rumen-digestible carbohydrates) for RDP and RUP level recommendations.

\section{ACKNOWLEDGMENTS}

We are grateful to FAPESP (Fundação de Amparo à Pesquisa do Estado de São Paulo, São Paulo, Brazil) for the scholarship (2015/03942-2) and CNPq (National Council for Scientific and Technological Development) for research funding (403469/2013-9).

\section{REFERENCES}

Allen, M. S. 2000. Effects of diet on short-term regulation of feed intake by lactating dairy cattle. J. Dairy Sci. 83:1598-1624. https:// doi.org/10.3168/jds.S0022-0302(00)75030-2.

AOAC International. 2000. Official Methods of Analysis. 17th ed. AOAC Int., Gaithersburg, MD.

Baker, S., and T. Herrman. 2002. Evaluating Particle Size. Feed Manufacturing. MF-2051. Kansas State University, Manhattan.

Brazil. 2009. Decree No. 6.899, Jul 15, 2009. National Project for the Control of Animal Experimentation - CONCEA, establish its rules for the operation and its executive secretary, create the Register of Institutions for Scientific Use of Animals - CIUCA, through the Law No. 11,794, of October 8, 2008, which provides for procedures for the scientific use of animals, and makes other provisions. Diário Oficial (da) União, Brasília, DF, 15 Jul. 2009. Accessed Jun. 15, 2015. http://www.planalto.gov.br/ccivil_03/_Ato2007 $-2010 / 2009 /$ Decreto/D6899.htm.

Barbosa, R. S., V. Fischer, M. E. R. Ribeiro, M. B. Zanela, M. T. Stumpf, G. J. Kolling, J. Schafhäuser Júnior, L. E. Barros, and A. S. Egito. 2012. Electrophoretic characterization of proteins and milk stability of cows submitted to feeding restriction.
Pesqui. Agropecu. Bras. 47:621-628. https://doi.org/10.1590/ S0100204X2012000400019.

Barros, L., N. Denis, A. Gonzalez, and A. Núñez. 1999. Prueba del alcohol en leche y relación con calcio iónico. Pract. Vet. 9:13-15.

Bijl, E., R. de Vries, H. V. Valenberg, T. Huppertz, and T. V. Hooijdonk. 2014. Factors influencing casein micelle size in milk of individual cows: genetic variants and glycosylation of $\kappa$-casein. Int. Dairy J. 34:135-141.

Bobe, G., D. C. Beitz, A. E. Freeman, and G. L. Lindberg. 1998. Separation and quantification of bovine milk proteins by reversed-phase high performance liquid chromatography. J. Agric. Food Chem. 46:458-463. https://doi.org/10.1021/jf970499p.

Broderick, G. A., and S. M. Reynal. 2009. Effect of source of rumendegraded protein on production and ruminal metabolism in lactating dairy cows. J. Dairy Sci. 92:2822-2834. https://doi.org/10 $.3168 /$ jds.2008-1865.

Carmo, C. A., F. Batistel, J. Souza, J. C. Martinez, P. Correa, A. M. Pedroso, and F. A. P. Santos. 2015. Starch levels on performance, milk composition and energy balance of lactating dairy cows. Trop. Anim. Health Prod. 47:179-184. https://doi.org/10 .1007/s11250-014-0704-4.

Casali, A. O., E. Detmann, S. C. Valadares Filho, J. C. Pereira, L. T. Heriques, S. G. Freitas, and M. F. Paulino. 2008. Influence of incubation time and particles size on indigestible compounds contents in cattle feeds and feces obtained by in situ procedures. Rev. Bras. Zootec. 37:335-342. https://doi.org/10.1590/S1516 $-35982008000200021$

Cooper, R. J., C. T. Milton, T. J. Klopfenstein, T. L. Scott, C. B. Wilson, and R. A. Mass. 2002. Mass Effect of corn processing on starch digestion and bacterial crude protein flow in finishing cattle. J. Anim. Sci. 80:797-804.

Ehrman, T. 1996. Determination of starch in biomass samples by chemical solubilization and enzymatic digestion. US Department of Energy, National Bioenergy Center, Washington, DC.

Fagnani, R., A. P. P. Battglini, V. Beloti, A. Uberbano, and J. C. Bronzol. 2016. Alcohol stability of milk from the perspective of x-ray diffractometry. Food Biophys. 11:198-205.

Fagnani, R., V. Beloti, and A. P. Battaglini. 2014. Acid-base balance of dairy cows and its relationship with alcoholic stability and mineral composition of milk. Pesqui. Vet. Bras. 34:398-402. https:// doi.org/10.1590/S0100-736X2014000500002.

Fai, A. H. T., and P. L. Cornelius. 1996. Approximate F-tests of multiple degree of freedom hypotheses in generalized least squares analyses of unbalanced split-plot experiments. J. Stat. Comput. Simul. 54:363-378.

Firkins, J. L., A. N. Hristov, M. B. Hall, G. A. Varga, and N. R. StPierre. 2006. Integration of ruminal metabolism in dairy cattle. J. Dairy Sci. 89(E-Suppl.):E31-E51.

Fischer, V., M. E. R. Ribeiro, M. B. Zanela, L. T. Marques, A. S. Abreu, S. C. Machado, V. Fruscalso, R. S. Barbosa, and M. T. Stumpf. 2012. Unstable nonacid milk: A solvable problem? Rev. Bras. Saúde Prod. Anim. 13:838-849. https://doi.org/10.1590/ S1519-99402012000300021.

Fonseca, D. C. M. 2018. Digestive metabolism and milk stability of cows fed non-fibrous carbohydrates sources and different rumen protein degradability. MS Thesis. Department of Animal Nutrition and Production, University of São Paulo, Pirassununga, SP, Brazil.

Fox, P. F., and P. L. H. McSweeney. 1998. Dairy Chemistry and Biochemistry. Thomson Science, London, UK.

Galyean, M. L., and L. O. Tedeschi. 2014. Predicting microbial protein synthesis in beef cattle: Relationship to intakes of total digestible nutrients and crude protein. J. Anim. Sci. 92:5099-5111. https:// doi.org/10.2527/jas.2014-8098.

Glantz, M., T. G. Devold, G. E. Vegarud, H. Lindmark Månsson, H. Stålhammar, and M. Paulsson. 2010. Importance of casein micelle size and milk composition for milk gelation. J. Dairy Sci. 93:14441451. https://doi.org/10.3168/jds.2009-2856.

Harvatine, K. J., and M. S. Allen. 2006. Effects of fatty acid supplements on milk yield and energy balance of lactating dairy cows. 
J. Dairy Sci. 89:1081-1091. https://doi.org/10.3168/jds.S0022 -0302(06)72176-2.

Hristov, A. N., R. P. Etter, J. K. Ropp, and K. L. Grandeen. 2004. Effect of dietary crude protein level and degradability on ruminal fermentation and nitrogen utilization in lactating dairy cows. J. Anim. Sci. 82:3219-3229.

Huntington, G. B. 1997. Starch utilization by ruminants: From basics to the bunk. J. Anim. Sci. 75:852-867.

Ipharraguerre, I. R, and J. H. Clark. 2014. A meta-analysis of ruminal outflow of nitrogen fractions in dairy cows. J. Adv. Dairy Res. 2:1-13. https://doi.org/10.4172/2329-888X.1000122.

Kuwahara, F. A., G. B. Souza, V. F. Soares, R. P. Ferreira, C. Costa, and P. R. L. Meirelles. 2015. Estimates of in situ digestibility and fibrous compounds in feeds for ruminants. Acta Sci. Anim. Sci. $37: 259-264$.

Lavialle, F., and E. Chanat. 2008. Lipid-deprived diet perturbs o-glycosylation of secretory proteins in rat mammary epithelial cells. Animal 2:491-499. https://doi.org/10.1017/S1751731107001309.

Li, S. S., J. S. Shen, D. X. Ren, and J. X. Liu. 2015. Effects of the processing methods of corn grain and soybean meal on milk protein expression profiles in dairy cows. Animal 9:267-274. https://doi .org/10.1017/S1751731114002225.

Marques, L. T., V. Fischer, M. B. Zanela, M. E. R. Ribeiro, W. Stumpf Junior., and C. M. Rodrigues. 2011. Milk yield, milk composition and biochemical blood profile of lactating cows supplemented with anionic salt. Rev. Bras. Zootec. 40:1088-1094. https://doi.org/10 1590/S1516-35982011000500021.

Martins, C. M. M. R., M. A. Arcari, K. C. Welter, A. Saran, C. A. F. Neto, and M. V. Santos. 2015. Effect of dietary cation-anion difference on performance of lactating dairy cows and stability of milk proteins. J. Dairy Sci. 98:2650-2661. https://doi.org/10.3168/jds 2014-8926.

Maulfair, D. D., and A. J. Heinrichs. 2012. Review: Methods to measure forage and diet particle size in the dairy cow. J. Dairy Sci. 28:489-493. https://doi.org/10.15232/S1080-7446(15)30396-X.

McDougall, E. I. 1948. Studies in ruminant saliva. I. The composition and output of sheep saliva. Biochem. J. 43:99-109.

Mertens, D. R. 2002. Gravimetric determination of amylase-treated neutral detergent fiber in feeds with refluxing in beakers or crucibles: Collaborative study. J. AOAC Int. 85:1217-1240.

Miyaji, M., H. Matsuyama, and K. Hosoda. 2014. Effect of substituting brown rice for corn on lactation and digestion in dairy cows fed diets with a high proportion of grain. J. Dairy Sci. 97:952-960. https://doi.org/10.3168/jds.2013-7046.

NRC. 2001. Nutrient Requirements of Dairy Cattle. 7th rev. ed. Natl. Acad. Press, Washington, DC.

Negri, L., M. Chavez, M. Taverna, A. Cuatrín, and A. Rubiolo. 2003. Determination of variables affecting thermal milk stability using a capillary method for evaluation of thermal coagulation time. Revista Argentinta de Lactologia 22:33-44.

Oba, M., and M. S. Allen. 2003. Effect of corn grain conservation method on ruminal digestion kinetics for lactating dairy starch concentration. J. Dairy Sci. 86:184-194. https://doi.org/10.3168/ jds.S0022-0302(03)73599-1.

Oliveira, A. S., R. F. D. Valadares, S. C. Valadares Filho, P. R. Cecon, L. N. Rennó, A. C. Queiroz, and M. L. Chizzotti. 2001. Microbial protein production, purine derivatives and urea excretion estimate in lactating dairy cows fed isoprotein diets with different non-protein nitrogen compounds levels. Rev. Bras. Zootec. 30:1621-1629. https://doi.org/10.1590/S1516-35982001000600032.
Oliveira, C. A. F., L. C. Lopes, R. C. Franco, and C. H. Corassin. 2011. Composition and physical-chemical characteristics of unstable non-acid milk received in a dairy plant of the state of São Paulo, Brazil. Rev. Bras. Saúde Prod. Anim. 12:508-515.

Orellana, R., P. Pulido, M. Briones, and A. Sarabia. 2004. Purine derivatives/creatinine ratio as an index of microbial protein synthesis in lactating Holstein cows. Pages 123-130 in Estimation of Microbial Protein Supply in Ruminants Using Urinary Purine Derivatives. H. P. S. Makkar and X. B. Chen, ed. Springer, Dordrecht, the Netherlands.

Ørskov, E. R., and I. McDonald. 1979. The estimation of protein degradability in the rumen from Incubation measurements weighted according to rate of passage. J. Agric. Sci. 92:499-503.

Santos, F. A. P., J. E. P. Santos, and C. B. Theurer. 1998. Effects of rumen-undegradable protein on dairy cow performance: A 12-year literature review. J. Dairy Sci. 81:3182-3213. https://doi.org/10 .3168/jds.S0022-0302(98)75884-9.

Savari, M., M. Khorvash, H. Amanlou, G. R. Ghorbani, E. Ghasemi, and M. Mirzaei. 2018. Effects of rumen-degradable protein:rumen -undegradable protein ratio and corn processing on production performance, nitrogen efficiency, and feeding behavior of Holstein dairy cows. J. Dairy Sci. 101:1111-1122. https://doi.org/10.3168/ jds.2017-12776.

Shen, J. S., L. J. Song, H. Z. Sun, B. Wang, Z. Chai, B. Chacher, and J. X. Liu. 2015. Effects of corn and soybean meal types on rumen fermentation, nitrogen metabolism and productivity in dairy cows. Asian-Australas. J. Anim. Sci. 28:351-359. https://doi.org/ 10.5713/ajas.14.0504.

Simas, J. M. C., A. V. Pires, I. Susin, F. A. P. Santos, C. Q. Mendes, R. C. Oliveira Jr., and J. J. R. Fernandes. 2008. Effects of starch sources and processing on nutrient digestibility and ruminal parameters of lactating cows. Arq. Bras. Med. Vet. Zootec. 60:11281134

Stumpf, M. T., V. Fischer, C. M. McManus, G. J. Kolling, M. B. Zanela, C. S. Santos, A. S. Abreu, and P. Montagner. 2013. Severe feed restriction increases permeability of mammary gland cell tight junctions and reduces ethanol stability of milk. Animal 7:11371142. https://doi.org/10.1017/S1751731113000128.

Van Soest, P. J., J. B. Robertson, and B. A. Lewis. 1991. Symposium: Carbohydrate methodology, metabolism, and nutritional implications in dairy cattle. J. Dairy Sci. 74:3583-3597.

Vaz Pires, A., I. Susin, F. A. P. Santos, C. Q. Mendes, R. C. Oliveira Junior., J. J. R. Fernandes, and J. M. C. Simas. 2008. Effect of starch sources and processing on performance and nitrogen metabolism in lactating Holstein cows. Rev. Bras. Zootec. 37:1456-1462. https://doi.org/10.1590/S1516-35982008000800017.

Walstra, P. 1999. Casein sub-micelles: Do they exist? Int. Dairy J. 9:189-192. https://doi.org/10.1016/S0958-6946(99)00059-X.

White, R. R., Y. Roman-Garcia, J. L. Firkins, P. Kononoff, M. J. Vandehaar, H. Tran, T. McGill, R. Garnett, and M. D. Hanigan. 2017. Evaluation of the National Research Council (2001) dairy model and derivation of new prediction equations. 2. Rumen degradable and undegradable protein. J. Dairy Sci. 100:3611-3627. https:// doi.org/10.3168/jds.2015-10801.

Zanela, M. B., V. Fischer, M. E. R. Ribeiro, R. S. Barbosa, L. T. Marques, W. Stumpf Junior., and C. Zanela. 2006. Unstable nonacid milk and milk composition of Jersey cows on feed restriction. Pesqui. Agropecu. Bras. 41:835-840. https://doi.org/10.1590/ S0100-204X2006000500016. 